\title{
On the Spirit of Rights and Abolitionism
}

\section{OLIVIER GRENOUILLEAU}

In Chapter V of his On the Spirit of Rights Dan Edelstein addresses the question of abolitionism. ${ }^{1}$ The subject is an extremely complex one. His study can in fact be traced back to the end of the $18^{\text {th }}$ century when the abolitionists themselves, headed by Thomas Clarkson, began to write its history. ${ }^{2}$ Since then, historians have not ceased to pore over the question, multiplying their approaches to it, notably in researching its sources, inevitably multiple because abolitionism involves several continents (initially Europe and the Americas, before the question of the abolition of slavery expanded to become a worldwide one with the establishment of the $19^{\text {th }}$-century colonial empires), extends over more than a century (from the 1780s when the movement begins to crystallize to 1888 when Brazil brings to a close, in America, the list of abolitions), and therefore concerns several generations of actors from different cultures. I will proceed in two stages. Beginning with the presentation and commentary of the thesis developed by Dan Edelstein, I will conclude by presenting how I perceive abolitionism; a means of comparing the history of ideas and history, and of underlining their differences and their complementary nature.

\section{The thesis: the interlocking of Roman law and ,free-market“ ideology}

The title of the chapter devoted to the issue immediately provides the roadmap: „Roman Law and Order: From Free-market Ideology to Abolitionism“. It underlines the idea of a process (,from“, „to") leading from Roman law to abolitionism, through an ideology associating freedom and the market. Abolitionism would this draw on two main sources; each is known to us, but they had hardly ever been previously associated in this way. Therein lies, in my opinion, the great originality of the thesis.

In particular, Edelstein insists on three points: 1 - Roman law (A) allowed the perpetuation of the idea of natural law; 2 - a natural law favourable to the development of the market $(\mathrm{B})$ is identifiable from the end of the $17^{\text {th }}$ century; 3 - at the end of the $18^{\text {th }}$ century liberal ideology and abolitionism came together $(\mathrm{C})$. The demonstration is akin to a syllogism: A leads to B, B can explain C, and so there is a link between $A$ and C. For this, the author bases his argument on an example from the $17^{\text {th }}$ century (Domat) and on analysis of philosophers of the following century. The framework is essentially French (Jansenism, physiocracy, encyclopedism).

1 Dan Edelstein, On the Spirit of Rights, Chicago 2019, pp. 118-142.

2 Thomas Clarkson, The History of the Rise, Progress and Accomplishment of the Abolition of the African Slave Trade by the British Parliament (1808], London 1968. 
Let us examine the first point: Roman law, he claims, constituted ,a lasting framework for the transmission and interpretation of natural law up though the eighteenth century" (p.118). In reply to this, one could say that the ancient sources for natural law are numerous, dating back equally to the Greek world and the Judaeo-Christian heritage, and that Roman law played a far from negligible part in the process of legitimation and codification of American colonial slavery. Bearing in mind these limitations and ambiguities, the author is nevertheless quite right to indicate that Roman law was capable of constituting a medium, among others, of transmitting the idea of natural law over time.

My caution does not imply any kind of criticism. It can be explained by the difference in approaches between history and the history of ideas. The historian is constantly contextualizing. Here, for example, he might be wondering whether we are talking about the process that led to the abolition of the slave trade (trade in human beings), the challenging of the system of slavery, or both, because if these movements are obviously connected, in practice, from a chronological point of view, they follow one another almost everywhere. The history of ideas encourages us to seek relationships between thinkers and theories, and then tends to consider that the movement leading to a transition from one to another or from some to others, was a logical one. Sensitive to the diversity of choices available to actors of the past, and thereby to the multiplicity of influences, as well as to the weight of events, the historian is always questioning whether this or that relationship, logical on paper, was the only one to emerge, and what role it actually played in practice, and in concrete terms.

In other words, he will distinguish between the possible sources of abolitionism, the way in which abolitionism developed as a movement, the obstacles it encountered, and the forces which enabled them to be overcome. He can even distinguish between different forms of abolitionism in trying to express the entity as a whole. Hence the nuance mentioned above: even if Roman law could have been a vector for transmitting the idea of natural rights, nothing proves to us that it always was, and that it was the only one to play this role.

This is, moreover, what Dan Edelstein indirectly shows, when he subsequently insists on the role of witness, in this vast process of transmission, played by Jansenist thought, in particular through the lawyer Jean Domat (Les lois civiles dans leur ordre naturel, 1689-1694). ${ }^{3}$ The author thus brilliantly underlines the existence of an original combination in a conservative writer and defender of absolutism - one associating natural right and divine right. What would be interesting to study is the connection between this thought and the legacy of Roman law. Does Domat derive much from it, or is his

Jean Domat, Les Lois civiles dans leur ordre naturel; le droit public, et legum delectus par M. Domat, avocat du roi au siège présidial de Clermont en Auvergne, Paris 1746, 3 vol. The first edition dates from 1689-1694. 
analysis essentially based on a kind of naturalization of the providential order? In the first case, we would be dealing with a genuine transmission. In the second, it would rather be the crystallization, under the pen of Domat, of a more autonomous and specific combination of a natural law applicable to social order. Continuing the analysis, we could also compare this interpretation of the providential order with others, either older (Saint Augustine) or later (Abbé Grégoire).

However this may be, I find here, with Domat, an element confirming one of the main ideas of La révolution abolitionniste: namely that the origins of the movement are to be sought mainly in the convergence, articulation and sometimes clash of two movements, one more theological and often "conservative“, the other secular and more often „liberal“ - movements leading both to a redefinition of the moral economy of the sacred. ${ }^{4}$ For the believer, trafficking and slavery are indeed sins of which one must be cleansed in order to gain salvation. A second reading sees in these plagues vices and signs of archaism which must be overcome by "progress“ in order to gain in virtue with, of course, multiple forms of arrangement between these two readings. Edelstein demonstrates the importance of a "sacred" reading of the world, as well, in a certain way, as its precedence over the second, more "profane" and contemporary to the Enlightenment (even if, there too, one could find earlier links with, for example, a Jean Bodin). We should add that economic „liberalism" and the market were also partly based on religious arguments. Does Jacques Savary not write, almost at the same time as Domat, that God has deliberately dispersed the resources that men need so that they may have recourse to trade, with the latter thus becoming a kind of providential instrument intended to encourage men to help each other (Le parfait négociant, 1675)?5

Edelstein goes further, ably demonstrating how Domat provides arguments capable of legitimizing the market: the need for work and commerce (which the author translates - perhaps hastily- as "productivity") and the idea that contracts derive from a natural order and not from specific political conditions. ${ }^{6}$ The demonstration is convincing: a law presented as "natural“ is capable of facilitating the development of the market. Two questions remain: is the law which Domat advocates derived from the ancient Roman heritage or is it an original combination?; is it really „natural“, or is it a kind of naturalization of an order primarily perceived and claimed as providential?

4 Olivier Grenoullleau, La révolution abolitionniste, Paris 2017. More extensive discussions of all the topics addressed in this article can be found there.

5 Jacques SAVARY, Le Parfait négociant ou Instruction générale pour ce qui regarde le commerce de toute sorte de marchandises, tant de France que des pays estrangers..., Paris 1675; critical edition by Edouard Richard, Genève 2011,2 vols. See also Olivier Grenouilleau, Et le marché devint roi. Essai sur l'éthique du capitalisme, Paris 2013.

6 "It is easy to see how Domat's interpretation of a natural commercial order could pave the way for the free-market ideal of allowing the economy to run its own course, without governmental meddling." (Edelstein, On the Spirit, p. 124; my italics). 
We come to point $\mathrm{C}$ of the syllogism, namely the articulation between the liberalism on which the market feeds and abolitionism. Several passages seem remarkable to me: the fact that one does not proceed ,automatically" from social naturalism and Rousseauist criticism to protesting against physical slavery (which returns to the metaphorical use of the idea of slavery, present from the Stoics onwards); the fact that the vogue for "feeling" and empathy studied by Lynn $\mathrm{Hunt}^{7}$ cannot solely, in the same way, explain the emergence of abolitionism; or even the developments relating to Montesquieu ${ }^{8}$ showing that the idea of nature can both lead to the rejection of slavery in general and the acceptance of it in certain "natural“ environments. All of this shows - and this seems to me essential - that abolitionism was not taken for granted at the end of the $18^{\text {th }}$ century. The first true abolitionists are few in number. The environment is hostile to them. Their success was by no means guaranteed.

At least three nuances are equally applicable here. ${ }^{9}$ It seems certain to me that empathy probably did not play the role that we sometimes think in the genesis of abolitionism. But can we say that ,the condemnation of slavery was largely unsentimental“" (p. 131)? This is true in many cases. In his Réflexions sur l'esclavage des nègres (1781), Pastor Schwartz (alias Condorcet) very rarely refers to the sufferings of slaves, his opposition being based essentially on reasoning. ${ }^{10}$ However, we could cite other cases, in the early stages of abolitionism, where feeling is present without being essential. Above all, once the movement has been launched, abolitionist propaganda plays on sentiment and empathy. I would say, then, that the latter undoubtedly does not play a major role in the genesis of abolitionism, but that it is essential in the dissemination of its message. A second point: the remarks concerning the role of international law in the possible genesis of abolitionist thought are fascinating (p. 133, in particular), but hasty and not closely connected to the rest of the exposition.

The last nuance concerns the link between abolitionism and the market economy. Edelstein established it on the basis of physiocracy, which subsequently, it is true, furnished the abolitionists with arguments. We could, however, have gone much further into this subject. The specialist bibliography on the association between „free labour ideology" and abolitionism is enormous. In a few words, we should remember here that

7 Lynn Hunt, Inventing Human Rights, New York 2007.

8 We should recall here that he was not an abolitionist in the genuine sense, even though he helped to undermine the ideological justifications of the system of slavery and was subsequently recognized as one of their own by many abolitionists.

9 Here we should touch on the most factual elements, such as the erroneous idea that Louis X (,the Quarrelsome") abolished or prohibited slavery in France, even if it contributed, several centuries later, to the establishment of belief in the principle according to which the fact of setting foot on French soil makes one free.

10 [Jean-Antoine-Nicolas Caritat marquis de CONDORCET], Réflexions sur l'esclavage des nègres par M. Schwartz, pasteur du Saint Evangile à Bienne, Neuchâtel 1781 (revised edition Paris 2009). 
the abolitionists used economic arguments: the work of a free employee would be more profitable than that of a slave, while trafficking, an ,infamous trade“, could be challenged by a „legitimate trade“, for the greatest profit of all, allowing Europe and America to buy the products of the free labour of Africans who would remained at home. It is then that things become complicated as we try to measure what is central and what appears to be more "tactical“ within the abolitionist argument. After years of research in this area, I have come to the conclusion that some abolitionists did indeed undoubtedly believe that wage-earning and "legitimate trade“ were good solutions. For many of them, however, the argument was more tactical than central, being intended to counter the idea that abolition would inevitably ruin America's colonies and their European metropolises. We should add that after the abolition of slavery in their colonies the British had to subsidize the production of "free sugar" in order to resist competition from Cuban and Brazilian „slave sugar" - and so we pass from the history of ideas to that of their insertion into history.

\section{Abolitionism from a historical point of view}

We may sometimes imagine that slavery was long taken for granted. In reality, in the Western world, slavery has always been a problem. If that had not been the case, why would it have been necessary to provide so many arguments in order to legitimize it? Did not even Aristotle, the author of the first theory of so-called "natural“ slavery that has come down to us, respond to the objections of one or more Sophists who remain unknown? That said, for millennia no one imagined that one day it could be ended. People considered "softening" the fate of slaves or facilitating the emancipation of some of them, most often in order to enhance the efficiency of the slave system. Societies without slavery hardly appeared except in utopias, and still do not. When they rebelled, the slaves themselves sought to extricate themselves from this system, without working to destroy it.

Humanity, for a long time, strove at best to procrastinate, or to find out in what cases the harsh realities of slavery might seem acceptable. This long period, from the „invention" of slavery in the Neolithic era to the end of the $18^{\text {th }}$ century, constitutes what I call the age of casuistry. From the 1770s onwards, while establishing connections between Europe and the Americas, a few individuals envisaged a new project. It was no longer a question of „reforming" slavery but of abolishing it. This constitutes a revolution in the long history of humanity.

Multiple theories have been developed to account for this turning-point. As authors of the first stories of abolition, the abolitionists explain it by the predominance of moral factors, emphasizing the figures of the „saint", the philanthropist and the philosopher. From the middle of the $20^{\text {th }}$ century, economics took over. It was stated that, in the first instance, the slave trade and slavery enabled Great Britain to obtain the profits necessary 
to launch the Industrial Revolution (idea which turned out to be wrong), and that, in a second phase, the system of slavery would have become a burden to a manufacturing nation wishing to market its products more effectively to the outside world. It is thus out of interest, and only for this, that the British would have abolished the slave trade (1807) and then slavery in their colonies (1833-1838). Then, setting themselves at the head of a kind of international crusade to incite the other Western nations to follow their example, they would have acted only to dominate them more effectively. Finally, happily abandoning the old theory which claimed that slaves were docile for many centuries, we have more recently been reminded that they had always - and in many ways - fought against the system that oppressed them. But if abolition was by no means the affair solely of white Anglo-Saxons and Protestants, can it only be explained by the action of slaves? Such an important movement, spanning almost a century (from the 1770s until the abolition of slavery in Brazil, the last American state to do so, in 1888), and concerning several generations of people and many countries, cannot be explained by a single factor.

So let us try, as Max Weber advocated, not to explain history from general theories but to understand how the actors of the past perceived the world. ${ }^{11}$ To do so, let us study the enormous amount of written material left by them. What do we see? The fact that abolitionist activists were primarily motivated by moral factors. Ulpian, a Roman jurist at the beginning of the third century $\mathrm{AD}$, could say that by natural law men are free and that, by the law of people living in society, they can be slaves. ${ }^{12}$ This did not bother him, any more than it troubled generations and generations of thinkers after him, because laws (divine, natural and human) could be dissociated from one another. At the root of the abolitionist project there is the idea that there are universal values, such as that of the natural equality of human freedom, and that these values must appear at the source of the laws of human beings living in society (the idea of the "encapsulation" of rights found in the very title of Domat's book, cited by Edelstein). If those values are of prime importance, and if those rights must be encapsulated, then we can think of abolition, and think of it in practical terms: it is by basing itself on the idea that fundamental rights must feature at the source of human law that abolitionism can envisage changing the world order by means of law.

Four elements, then, make it possible to account for the crystallization of this project - a term that I use deliberately. Historians looking for the source of this or that idea will almost always find an example earlier than what they had believed to be the first. Ideas circulate and recombine in time and space. It is therefore useful to take an interest

11 Max Weber, Économie et société (posthumous 1921), Paris 2003, 2 vol. La ville (An extract from vol. 2 of Wirtschaft und Gesellschaft), translated by Philippe Fritsch, Aubier 1982. The whole volume 2 was published with Pocket in 2003 as a reedition subtitle: L'organisation et les puissances de la société dans leur rapport avec l'économie), 2nd edition . Les Belles lettres, 2013.

12 Ulpian, Digesta, 50, 17, 32 
not only in the relationships between them, but in the way in which old principles sometimes manage, at a given time, to combine in a new and original way.

Regarding abolitionism, the first element of crystallization lies in the convergence of secular (Enlightenment) and Christian (Catholic and Protestant) morality, as faith and reason are not necessarily opposed in matters of abolition - quite the opposite. Let us recall on this subject how important the idea was of a decline, both moral and political, associated with providentialist readings of history in the "nationalization“ of abolitionism in late $18^{\text {th }}$-century England. Second point: the followers of these morals do not wait for progress or the end of time to do their work; they campaign to transform the world as it is. These are morals in action which converge in order to „regenerate“ the world (to use terms, heavy with meaning, from the $18^{\text {th }}$ century). The Essenes and Therapeutae of ancient times might forbid slavery, just like the Druze in the $11^{\text {th }}$ century, but they tolerated it outside their community. In this sense they were not abolitionists. The same is true of Montesquieu, who played an essential part in challenging slavery without campaigning to make it disappear.

Third point: as part of a broader democratization process, the abolitionist discourse was heard by individuals actors adopting their stance in accordance with their experience and their conviction, and no longer solely in accordance with tradition. In 1698, the director of matters of conscience at the Sorbonne, Germain Fromageau, answered the following question: can we, in all conscience, engage in trafficking? ${ }^{13}$ He cites the Bible, the Fathers of the Church, and examples from Greek and Roman antiquity without anyone knowing what he personally thinks of it. After long digressions, he comes to the conclusion that one cannot indulge in trafficking before changing his mind a few lines later, noting that it is legitimate if it allows one to save the souls of pagans by baptism. In 1788, speaking to his faithful followers in London, Pastor James Dore did not review the whole body of sacred texts, the doctrines of the Church Fathers, and examples from past civilizations to convince them. He told them that as men, Christians and British people who loved freedom, they could not tolerate trafficking without being condemned to the flames of hell and leading their nation to its destruction. ${ }^{14}$

To these root causes are added multiple forms of resistance by slaves. It was maroons (i.e. slaves who fled from the plantations) that led, in the 1760 s, to an initial awareness in Europe of the "problem“ of slavery (echoes of marronage being able, in a way, to be associated with the vogue for "feeling“ of which Lynn Hunt speaks). Some freed themselves from their chains, as in San Domingo, from 1791 onwards. Others, once liberated,

13 Germain Fromageau, Dictionnaire des cas de conscience, décidés suivant les principes de la morale, les usages de la discipline ecclésiastique, l'autorité des conciles et des canonistes, et de la jurisprudence du royaume, Paris 1733.

14 James Dore, Sermon on the African Slave-trade Preached at Maze-Pond, Southwark, Lord's Day Afternoon, November 30, 1788, London 1788. 
campaigned in the ranks of the abolitionists. While not all forms of slave resistance should be confused with abolitionism, multiple and complex links were forged between the struggles of slaves and those of abolitionist militants in Europe and the Americas.

Finally, to the factors behind the emergence and crystallization of the idea of abolitionism we may add those responsible for its success, as the outcome of the project was not a foregone conclusion for at least three reasons: 1 - it crystallized while the American colonial slave system was at its peak; 2 - and also at a time when American racial prejudices against black populations were tending to spread into some elites circles in Europe; 3 - at the very time when the wave of revolution was making over-bold enterprises like abolitionism appear suspect. Abolitionism was not a self-evident phenomenon, and it took a century for it to apply to the Americas as a whole.

Noting without judging, let us observe that four things enabled its success - first and foremost, the fact that this radical project was served by a reformist method of action, the abolition of slavery often occurring only after that of the slave trade and after long processes. Radical but ephemeral, the French abolition in 1794 itself seems to confirm the fact that those who succeeded took the path of reformism. In fact, in the Americas there were only two abolitions that were at once total, immediate and lasting: in San Domingo, as a result of the slave revolt, and in the United States after the American Civil War. Secondly, this reformism was served by alliances of circumstance or reason between political groups which were sometimes in opposition to each other. We should add the use of an argument combining the Just (abolition is a moral imperative) and the Useful (the advantages of wage-earning and „legitimate trade"), for if the abolitionists are driven by primarily moral arguments, they must convince their contemporaries and respond to the arguments of slavers brandishing the standard of ruin. Finally, the force of law was also fairly widely used (diplomatic and military pressure from the Royal Navy, for example).

In conclusion, I would like to salute the work of Dan Edelstein. His approach is not that of the historian, thus underlining the communication difficulties that may exist between different fields of research. In his references and bibliography, the author does not cite any work which is, strictly speaking, devoted to the history of abolitionism. In the same way, we can read many works on the links between trafficking and industrialization without references either to trafficking or to industrialization. Today's division of scientific work is such that this bias is becoming generalized. It is therefore all the more remarkable and fascinating to see how here the history of ideas and history can converge, whether this involves a search for links becoming combinations (physiocratic order and philosophy of rights, for example), or equally the highlighting, from different angles, of common elements at the roots of abolitionism (providential order and the ability to conceive the hierarchical articulation of rights, as in the case of Domat).

Translated by Susan Reynolds 
Olivier Grenouilleau

\section{On the Spirit of Rights and Abolitionism}

Abstract

The article examines the thesis that abolitionism in France was encouraged by Roman law and free-market ideology. Grenouilleau stresses that abolitionism was much more than we usually think. It was not only an effort to reform or renounce the participation of one's country in the slave trade, but an effort to eradicate the slave trade and slavery everywhere. In an effort to identify its history, he distinguishes between its possible sources (i.e. retrospective deduction) and its real developments (i.e. real-time reconstruction). The essential factor was the convergence of a conservative „theological“ movement with a secular „liberal“ one, in which free-market arguments might have been deployed merely as a tactical device. While Grenouilleau agrees that sentimentalism may not be seen as the source of abolitionism, he argues that it was essential to the dissemination of its message. In the long-term perspective, the $18^{\text {th }}$ century appears to be a turning- point closing the long period of casuistry and starting the era of abolitionism. It included even countries such as Brazil which abolished slavery only in 1888. The reasons for this turning-point seem to be mainly moral ones.

KEY WORDS:

slavery; slave trade; France; abolitionism; Christianity; natural law; free market 